\title{
ACCOUNTING FOR MATERIALISM IN FOUR CULTURES
}

\section{- GÜLIZ GER}

Bilkent University, Turkey

- RUSSELL W. BELK

University of Utah, USA

\begin{abstract}
Accounts for materialism are examined based on qualitative research in Romania, Turkey, the USA, and Western Europe. Various spontaneously offered accounts reconcile the discrepancy between the belief that materialism is bad and materialistic consumption behavior and aspirations. These accounts include justifications - passionate connoisseurship, instrumentalism, and altruism - and excuses - the compelling external forces, the ways of the modern world, and deservingness. The differences in accounts can be understood culturally and historically. In negotiating the 'bad' material world with their own consumption worlds, informants draw from various ethics prevalent in their cultures to moralize their personal materialistic consumption. Our findings suggest ways in which materialism, moralized by local accounts, is able to grow globally in spite of its condemnation.
\end{abstract}

Key Words $\bullet$ accounts $\bullet$ consumption $\bullet$ cross-cultural research justification $\bullet$ materialism $\bullet$ morality of consumption

Consumption is increasingly winning the center stage in life throughout the world (e.g. Belk, 1988; Friedman, 1994; Ger, 1997; Ger and Belk, 1996a; Kemper, 1993; Miller, 1995; Shultz, Belk, and Ger, 1994). The growing role of material life is accompanied by a growing multidisciplinary literature on the consumption-based orientation to happinessseeking called materialism (e.g. Belk, 1985; Brewer and Porter, 1993; 
Campbell, 1987; Csikszentmihalyi and Rochberg-Halton, 1981; Dittmar, 1992; Douglas and Isherwood, 1979; Ger and Belk, 1996b; Inglehart, 1981; Leach, 1993; Lears, 1994; Mukerji, 1983; Needleman, 1991; Richins and Dawson, 1992; Richins and Rudmin, 1994; Rudmin and Richins, 1992). Materialism has been variously defined as an economic orientation to life giving precedence to economic values over other values such as freedom, civil power, aesthetics, and friendship (Inglehart, 1981), the 'ceaseless pursuit of the "good life" through consumption' (Fox and Lears, 1983, xii), the importance a consumer attaches to worldly possessions (Belk, 1985), or the belief in the desirability of acquiring and possessing things (Richins and Dawson, 1992). Whether for pleasure seeking, self or relationship definition/expression, or status claiming, it is an excessive reliance on consumer goods to achieve these ends, a consumption-based orientation to happiness-seeking, a high importance of material issues in life that is generally taken to be materialism.

Crass materialism is not something that objectively exists and that is either good or bad. Rather, it is a culturally agreed-upon understanding of a mode of consumption that is generally regarded negatively. This can be seen in numerous condemnations of materialism by all major world religions and in numerous other critiques (Belk, 1983). A basic rationale for such condemnations is the opposition of individualistic and self-indulgent material consumption to altruism and social welfare. There are also arguments that focusing on our relationships with things alienates us from relationships with people (e.g. Wachtel, 1989), that material desires cause property crime (e.g. Coleman, 1992), and that material greed is destroying our planet (e.g. Seabrook, 1978). Such consumption also is believed to provoke potentially destructive envy. In light of such criticisms, it is not surprising that based upon interviews with over 2000 Americans, Wuthnow concludes that:

... materialism is a generalized symbol that stands for evil in our culture. In a society that has largely ceased to personify evil in some tangible being (Satan), materialism has become the devil. Sensing that something is wrong with society, people easily point their finger at materialism. (Wuthnow, 1994: 177)

Despite the humanistic, social, environmental, and religious discourses against materialism, consumption is increasingly more prevalent and high levels of consumption are generally taken to constitute the good life. This is a contradiction at the aggregate level. How is it that consumers can consume endlessly and pursue apparently insatiable desires despite numerous condemnations of materialism and materialists?

When materialism is regarded negatively by a culture, members of this culture must either avoid consumption that fits this cultural definition, attempt to reconstruct the cultural meaning of materialism, or 
suffer social condemnation by embracing a mode of consumption generally considered to be bad or even evil. In a part of the present study that is not reported here, we found that university students and other primarily middle-class consumers in Western Europe, Turkey, the US, and Romania indeed regard materialism and materialistic people negatively (Ger and Belk, 1998). While it may overstate to regard materialism as the contemporary manifestation of evil in the world, it is clear from our data that the social construction of materialism is overwhelmingly negative in each of the four cultural contexts studied. Informants saw materialism as a false path to happiness via consumption, an excessive orientation to consumption ending in a state of being dominated by things, a weakness arising from insecurity, a harmful competition for status through possessions, and a valuation of things over people. They resented and disdained materialistic people. But despite the negative connotations of materialism, most of those studied had personal consumption patterns and aspirations that, seen from a distance, appear as highly materialistic. The data for the present analysis focuses on how informants account for this apparent contradiction. We sought to gain a grounded understanding of how people legitimate their materialistic consumption in each of several cultures.

The sociological category of accounts involves 'statements made to explain untoward behavior and bridge the gap between actions and expectations' (Scott and Lyman, 1968: 46). Accounts have also been treated in a diverse array of other fields including psychology, psychotherapy, philosophy, criminology, communications, law, and political science. People or groups try to account for their behaviors so that they appear ethical, moral, legal, consistent, and rational to some audience (including themselves) that is perceived as scrutinizing them. Explanations for questionable behaviors can be offered sincerely or they may be offered self-protectively in order to avoid or minimize internal feelings of guilt, foolishness, or hypocrisy, as well as to reduce external sanctions, condemnation, or challenges to legitimacy (Baier, 1986).

A demarcation is often made between justifications and excuses, although some object to the necessity of such a distinction (e.g. Corrado, 1991). Justifications accept responsibility for an action but seek to deny that the act is wrong or worthy of blame, while excuses deny full responsibility for the act (e.g. Hunt and Manning, 1991). Greenawalt offers the example that:

If Ann acknowledges that she hit Ben but did so to prevent him from detonating a bomb, she offers a justification; if she says that she decided to hit him because she was insane, she offers an excuse. (Greenawalt, 1986: 89)

A full review of the various accounts literatures is beyond the scope of this article. Empirical studies suggest that there are diverse possible accounts (e.g. Glass and Wright, 1992; Hong and Duff, 1977) and that 
accounts are not perceived by others to be satisfactory explanations (McGraw, 1990). Hamilton and Hagiwara (1992) found that apology was more common in Japan and denial was more common in the US. However, there are few comparative ethnologies or cross-cultural studies involving accounts and their perceived acceptability.

The study began as an investigation of how people in different cultures understand materialism. The accounts' focus of the present study emerged as we were struck by the apparent inconsistency between informant condemnations of materialism in voicing their values and criticizing other people's consumption orientations versus their own ostensibly materialistic behaviors. The accounts detected differ across cultures and seem to be related to the religious, historical, cultural, economic, and political environment of each. In the following sections we introduce our methods and then examine the various accounts for materialism offered within each culture. We conclude with an assessment of implications for understanding materialism accounts from a cross-cultural and socially constructed perspective.

\section{THE STUDY}

Data consisted of focus groups, depth interviews, informant journals, and participant observation. Part of the data come from university students in these countries and part from other people. The Western European data were collected at INSEAD (Fontainebleau, France) and Odense University (Odense, Denmark). INSEAD is an international institution where the student body is primarily European, with the majority being French, English, and German. The US data were gathered at two large public universities - one western and the other midwestern, while the Turkish data were also from two large universities - a private one in Ankara, and a public one in Istanbul. In Romania, students were from the University of Craiova, while depth interviews with a broad crosssection of Romanians in Craiova, Cluj, Sibiu, and Bucharest were part of a year's participant observation during 1991-1992.

In each country, except Romania where no journals were obtained, materialism journals were completed by business major undergraduates and MBA students. Male respondents constituted from 49 percent of those studied (in Turkey) to 70 percent (at INSEAD). In the US students also conducted two depth interviews each (with non-students) after completing their materialism journals. The materialism journals as well as depth interviews pursued a set of topics suggested by the earlier focus groups. The focus groups and the interviews and journals were conducted in Turkish, English, and Romanian, with English being used at INSEAD where it is the lingua franca. Of these informants 63 percent were students. 
The focus groups lasted for one-and-a-half to two hours and included 106 people in groups ranging from 3 to 8 . All were business or economics students, except in Romania where one group was composed of residents of a small prosperous mountain village and two other groups were composed of young professionals in Bucharest. The groups were from 50 to 75 percent male. We moderated all focus groups except for an all female focus group in the US (run by an experienced female moderator) and the Romanian focus groups (moderated by a male Romanian graduate student). The discussions started with 'Let's talk about the importance people attach to worldly possessions as sources of satisfaction in life; that is, the consumption-based orientation to happiness and satisfaction seeking.' We encouraged participants to talk about their own and their friends' experiences. The concepts of consumption orientation and materialism were probed, along with the participants' consumption experiences and aspirations, their valued possessions, their relationships with possessions, and the people whom they consider to be materialistic and nonmaterialistic. Other topics included styles of consumption, care of possessions, and how money and possessions are seen to affect people's happiness.

In subsequent depth interviews and self-reported journals, we told informants that the study concerns the importance of things in life and their relation to satisfaction and well being and we asked about a similar set of topics. A total of 135 informants completed journals and 154 were personally interviewed in the 4 regions. Given the large amount of data collected, much of the analysis was aided by computer retrieval of transcribed material. Initial analyses were done retaining the original language, with later translations used to facilitate discussions between the two of us and to prepare this report.

\section{ACCOUNTING FOR MATERIALISM: FINDINGS}

Thinking about materialism for our informants was both an explication of material cultural norms and a dialogue (with self, with the researchers, or with the focus group) about material attitudes, values, and lifestyles. For the younger student informants, the dialogue was more about goals and expectations. In each case, working through an understanding and evaluation of personal consumption in light of cultural norms was an involving and often emotional experience for these informants. This is one evidence of the high importance of material issues in our lives.

Perhaps it should not have been surprising in light of the negative characterizations of materialism obtained and the explicitly materialistic lifestyles or aspirations of most of those studied, that informants spontaneously offered a variety of accounts that attempt to reconcile this 
apparent inconsistency. The two primary types of accounts offered were the justification that the informant practices a type of materialism that is positive rather than negative (and when 'properly' understood is not really materialism at all), and the excuse that, while materialism may be bad, there are nevertheless salient reasons to be materialistic. There were variants within each of these types of accounts. Those claiming the justification that their type of materialism is positive said that their own consumption is elevated either through connoisseurship, instrumentalism, or altruism. Among those who admit that they engage in harmful materialism, the major excuses are that external forces compel it, that it is the way of the modern world, or that they deserve it due to prior deprivations or as a reward for success.

\section{Justifying: My Materialism is a Good Materialism}

\section{I am a Joyous, Passionate Connoisseur, Not a Vulgar Materialist} This justification can either involve the admission of materialism but the reconstruction that it is a positive thing, or else the denial of the label of materialist by redefining materialism itself. For the Western European informants consumption of faddish technological or fashion products is associated with American and Japanese consumers and is cited as negative, materialistic, and in contrast to their own more cultivated consumption. For example, Diana, a 28-year-old British student, aspires to own art, books, music, and culturally enriching travel and education experiences, and says she loves to see money well spent rather than squandered on ostentatious and flashy consumption. Negative materialism is seen by these informants as involving nouveau riche vulgar consumption:

[Materialism is the] American way of life: cars, color TV in every room, all sorts of durables, electronics, gadgets, and mechanical things, the latest stuff. (F28, British)

Money is a measure of success in the USA, whereas education and recognition are in France and Europe. (M29, French)

Americans spend to show that they have money. They enjoy that show; they waste the money, the possessions. Europeans just enjoy spending, having fun, living through money. (M27, Austrian)

Among the Turkish students, ostentation was ridiculed and disparaged in reference to newly rich formerly rural Turks who pursue status through conspicuous consumption. New terms for these people such as kro (crude) refer to their lack of subtlety and refined taste.

Informants using this justification see a materialist and a nonmaterialist pursuing the same product or experience for quite different 
reasons: 'buying a painting for the signature, or price, or because "it is the thing to have"' versus 'enjoying looking at it, being excited by it, moved by looking at it'. The latter motivations are taken as positive whereas the former are seen as damning signs of negative materialism.

Both a materialist and a nonmaterialist can buy the same glass. But the nonmaterialist enjoys the glass, its design, shape, visually, artistically; for example, he may be an artist who likes the glass as an art object, for the beauty in it. The materialist just has the glass. (F28, Dutch)

When someone appreciates the beauty of an object, being what it is, for its meaning, or savoring the moment, then consumption is not materialistic. (F26, French)

Such comments also imply a coldness in the materialist's relation to possessions and experiences. Passionate sensory experiences instead are seen to imply a warmth - an emotionalism that the gauche materialist is seen to lack. Such tendencies are seen as related to vulgar materialists' unwillingness or inability to directly express or reveal themselves. They instead are seen to rely on possessions that are impersonal and bought according to fashion or perceptions of what a person ought to have rather than according to personal tastes. This coldness is also consistent with a view voiced by Turkish and some Western European informants that a narrow, intense, and calculated focus on the objective value of the thing, impedes the sensual enjoyment.

Unlike a materialist, I do not mind how much a dinner or a night out costs, as long as I enjoy the ambiance - the evening - thoroughly; if I am having a good time. (M25, Turkish)

This opposition to rational calculation appears to be based on a certain romanticism.

Consumption is also regarded as justified if it involves creating and cultivating self (self-improvement - music, films, plays, travel, books), enjoying nature, providing sensual, aesthetic, and intellectual pleasures.

I always daydream about the newest inventions within the field of electronics. The achievement of getting even better sound and better picture can make my life happy. I am a musician. (M24, Danish)

Money and possessions can bring happiness if used right, especially if spent on art, sports, travel, leisure, help develop oneself. (F20, Turkish)

Connoisseurship experiences include intellectual curiosity, aesthetics, and culture for the non-American informants, especially for Western Europeans. Vulgar materialists, on the other hand, are seen to mostly 'spend on expensive or flashy cars' or 'the latest electronic toys'. Nonmaterialists are seen to spend 'on art, like exhibitions, theatre, as well as buying art, traveling, on family and friends, family parties, dinners' 
(M28, German), 'on family parties, travel, especially to see and learn [about] other cultures' (F26, Danish), and 'on air fares rather than hotels' (M29, British). Among Romanians consumption of books, music, and art was seen as part of a prior idealism being swept away by a tide of materialism.

Ask people how many books they've read since 1989. Personally, I love books, but I have no more time. I have to work more because now I want more things. To be culturally and spiritually satisfied [is not possible]. (M30, Romanian)

\section{Terminal Materialism is Bad, but Instrumental Materialism is Good}

If refined aesthetic and emotional consumption is claimed by non-Americans to provide joi de vivre, instrumental materialism is claimed by Americans (and some others) to transcend materialism. They suggest that possessions and the experiences that money buys can bring happiness if they are tools for other, nonmaterial, sources of happiness. The conception implicit here is that which Csikszentmihaly and RochbergHalton (1981) called instrumental materialism as distinguished from terminal materialism.

Well, you look at people, like what can I get, bigger house, more possessions. You wonder what is important to them.... You know conspicuous consumption when there are people that just cannot buy enough, spend enough, have enough, you know. You see that, and maybe that, I don't know, maybe not so much competition with the neighbor, but just want, want, want, for the sake of wanting because it is there. (F43, American)

The alternative to this unfulfilling terminal materialism is seen as empowering instrumentalism. A 31-year-old Romanian man who works in a bank illustrated this in noting 'I am not eager about money. But you know these kinds of people are doing more, a lot more things, than the average people.' It is this doing more and living a more enjoyable life (and, for Turks and Romanians, a more secure life) rather than necessarily having more that is seen to provide the link between consumption and happiness. After years of consumer deprivation under Ceauçescu, a 25-year-old Romanian woman experienced a change in perspective recently:

When I was 18 I could swear that money is not important for people's happiness. But now I can say that [it accounts for] 80 percent of people's happiness. Actually I don't think it's happiness; I would call it satisfaction. It can bring you a certain stability and feelings of prosperity, welfare.

In Romania, before the 1989 revolution people could be happy with few material goods because there were no alternatives and everyone had few 
things. But now as some become better off materially, others who fail to do so feel worse about their condition. Materialism is always relative, and with the opening of a window on the world, Romania's relative poverty is now palpable. Hence, many respondents believe that goods can be instrumental to happiness and contentment. Angela, a 25-yearold Romanian woman, described the happiness she experienced through consumption following the Romanian revolution:

The man I loved, in the house I liked; I got the sweets I liked; watch a good movie, drink a good wine. I felt happy. How I ate that happiness. It was like eating apples. I'm looking forward to building such happiness [again], but [this] is very difficult since everything around is turning and changing. It's the transition period, which has brought risks and social costs.

Such comments suggest a consumption-based empowerment involving personal control of life, independence, and security. Turks and Romanians commonly saw spending money as a way to gain control over their everyday lives.

Money is a change agent, a 'tool'; you can buy and do things. Money is power, it takes money to acquire things, and to do and realize certain things. (F24, Turkish)

Consuming more [makes you feel] more secure about the future: comfort, prosperity, stability. (F25, Romanian)

Turks and Romanians, more than those of other cultures, emphasized independence, power, and security as reasons why instrumental consumption can bring happiness, and conversely, why the poor cannot be happy. In contrast to the traditionally authoritarian control of the state, school, work, and family, consumption is seen to offer freedom. This may explain an account by Paul, a 34-year-old American shoe clerk:

I grew up with a fellow that really wanted nothing more than a boat and a camper, and the trucks and stuff to tow it ... that's all he wanted in life. ... and that's not intrinsically bad.

Still, such empowering instrumentalism is an egoistic justification. A quite different justification involves altruism.

\section{Spending Money for the Benefit of Others is Good}

Many informants were careful to note that they donate or plan to donate a portion of their incomes to charity. Others justify their spending as benefiting their loved ones. All respondents, but particularly Western European and Turkish informants, regard shared consumption to be a means to happiness if and when it contributes to warm and loving relationships with friends and family. 
Good uses of money would include doing things that make you and your family happy. Bad uses would include buying something you don't really want or need but your neighbor has it and you don't want to be outdone. So your motivation is corrupt. (F28, American)

Going out to a nice restaurant, eating good food with good wine, enjoying the time with friends is great fun. That is not materialistic. (M26, Turkish)

[For a nonmaterialist the] Good life is to have a good family and social life, in addition, to have a comfortable material life without facing financial distress, and being able to use possessions at the times and places needed, that is, sharing and feeling happy to share these with the loved and valued ones. (F22, Turkish)

Conversely, one Romanian woman noted that 'The poor can't be happy - they can't satisfy the material desires belonging to people they love.'

Charity, whether to family and friends or to others, was also taken to be a sign of good, nonmaterialistic, consumption. Generosity in giving personal gifts to the poor is emphasized as a crucial nonmaterialistic human value.

Both [of my nonmaterialistic parents] give a lot of time and money to charity. [They are] Generous to all family/employees for presents at Christmas or if money is needed to buy something 'useful'. . . . They tend to have a paternalistic attitude to the less well off. (F27, British)

A friend who is not materialistic spent 70 percent of his income during his first year of work on his family: [he] bought an automatic washing machine and refrigerator for his parents, paid for the educational expenses for his sister, or sent money home. He did not spend it on clothes and cars like most of his colleagues did. (M28, Turkish)

For collectivist Turks, materialism is steeped in individualism. But to spend money on family is communal and valorized. Like joyous connoisseurship and instrumentalism, altruism in consumption is seen to transcend or negate materialism.

Implicit in each of the three justifications is a reflection of Marx's definition of materialism. ${ }^{1}$ Marx argued that materialism is the detachment of goods from their role in human enhancement and attachment of goods to economic values (such as market or exchange value); that is, stripping goods from their sentimental value and making them represent abstract values such as mere price (see Stallybrass, 1998). Marx's view seems to have been popularized and internalized: informants state that consumption is justified when used for self enhancement (joyous connoisseurship and instrumentalism) or social enhancement (altruism) but not when it is turned into mere abstract signs of wealth or price. These three justifications construct informants' practices and aspirations as good materialism, which they think should not even be labeled 
materialism. Their feelings of joy, cultivation, empowerment, charity and altruistic sociality set them apart from the materialists who might have similar practices and aspirations but why and how they consume are seen to be different.

When informants admit that their consumption practices or aspirations are indeed bad, they resort to excuses: they either place the responsibility on others - the society or the idealized modern world (which also normalizes such practices), or suggest that they deserve to be a little bad now because they have paid their dues: they have already suffered or worked hard.

\section{Excusing: Materialism is Bad, But ...}

A second set of accounts for materialistic consumption does not attempt to reconstruct a variant of materialism as being good. Rather, these excuses admit to personal materialism and accept that it is bad, but nevertheless cite explanations and reasons for such consumption patterns.

\section{Society/The Media/The Environment Made me Do It}

In this view, materialism is caused by irresistible external influences. Succumbing to these pervasive pressures is seen as inevitable.

Our society just ever since you're little just throws all these things at you through the $\mathrm{TV}$, through the newspapers, through the magazines: To be successful you have to acquire all these things in our culture, and that's not right. (M29, American)

Society is telling me that that is the way you do it. The one that dies with the most toys wins. (M28, American)

I behaved materialistically when I lived in a consumer society - Hong Kong. People around me were three to four years older than I and had more purchasing power. They bought a stereo I wanted one too. I was young and impressionable; I was influenced by them. (F28, French/English)

Materialism is seen to be part and parcel of being and living in 'this world', and people who do not consume are seen not to be a part of society. Across cultures, many described a nonmaterialist to be someone who 'rejects the society or is asocial', 'is detached from this world', and as someone who 'doesn't care or think about the future, lives in his own world', such as a monk or a yogi.

Romanians see materialism as a condition that has been forced upon them by the changes in the economy since the 1989 revolution. With the opening of the country's political system, consumption images and luxury products from the world's consumer cultures have come flooding in. And with the opening of the country's economy, means have become available to acquire more money through second and third jobs 
as well as entrepreneurship. As one man put it when he was asked to describe a nonmaterialistic person, 'It is hard to believe there is someone like that in today's Romania.' Several Romanians said that their lives had become dominated by a 'consumption fever'. The belief is not that some people are materialistic and others are not, but rather that all of Romanian society is becoming more materialistic. A part of adapting to capitalism is seen to be opting for a pragmatic materialism over a more idealistic emphasis in life. Angela (F25) said of her friends who abandoned interests in culture, books, and art in order to pursue consumer goods:

Usually they are intelligent people who [have] made a clear decision. I talked to them and they said, 'Yes, it would be great to stay the same, but I would be someone with interesting ideas and an empty stomach, with no house or food.'

Idealism was seen as a luxury afforded by great wealth and something that the vast majority of Romanians could not aspire to under the new market economy. The 31-year-old man who works in a bank saw such idealism as currently possible only for the idle rich:

I don't think there is anybody not interested in money. Maybe the son of a millionaire, who doesn't ask for money, he has that money all the time. The only things he wants are to paint, to write poems, to travel.

Nonmaterialists were seen to include painters and philosophers. A part of their genius was in being so fulfilled with their work that they were willing to sacrifice material comforts in order to pursue it. But however romantic such lifestyles were to Romanian informants, they saw themselves as preferring material comforts.

It is very easy to be a nice, decent, moral person when life has never forced you to be otherwise. You live there in your 'nest' and serve the truth. But when life challenges you, you can't be the same and [you] start to change, become mean, materialist, selfish.

The view of decency and morality here is shaped by Marxist ideals that saw property and capitalism as crimes. While communism is now widely lampooned by Romanians as a mistake, the Marxist ideals behind it are not so easily put aside. But the only pragmatic alternative in contemporary Romania is seen by most to be making as much money as possible in order to enjoy a richer material lifestyle. As one young man put it, 'Before the revolution a university teacher, though badly paid, was somebody. Now a university teacher without money is a fool.' As another man assessed the situation, 'Consuming less is a weakness. When you can't afford buying something and have to give up, giving up is to lose.' With attitudes such as these it is easy to see why Romania scored ahead 
of a dozen other countries in Europe, Asia, North America, and Oceania on a quantitative measure of materialism (Ger and Belk, 1996b).

\section{It's the Way of the Modern World}

For the Turks the environment or 'this world' consists of modernity. Comparisons are made between local Turkish society and the 'modern' Western world. Since Atatürk in the 1920s, modernization and Westernization have been idealized in Turkey as means to development, progress, and civilization, with an added emphasis on marketization since the mid1980s (Ger, 1992, 1997). Urbanization and class mobility, on the increase since the 1980s, fuel aspirations to be modern. There is no pointing to the US as exemplifying materialism, but reference is made to 'the West' as an ideal model of consumption. Such consumption is considered normal - 'everyone else does it too'. This type of excuse has been detected elsewhere and labeled the consensus defense (Hamilton and Hagiwara, 1992; Snyder, Higgins, and Stucky, 1983). In contemporary Turkey materialism is seen as something that necessarily accompanies progress and is integral to 'the good life'. Informants acknowledge that they enjoy the novelty of abundance and that the availability of high quality products stimulates their wants. Consumption is seen to be a necessity in order not to be behind the times; in order to be 'living like a human being of the contemporary world'. There is also a widespread belief among the Turkish informants that people raised during the 1980s in a more affluent Turkey, experiencing major economic growth and liberalization (see also Ger, 1992; Ger, Belk and Lascu, 1993), are more materialistic than previous generations.

In recent years we see so many things on $\mathrm{TV}$, in the shops, all around. Consumption was less important for our parents, but now because there are more goods, more variety, and more advertising, consumption has become more important, we want to consume more. (M26, Turkish)

Unfortunately life conditions, becoming tougher day by day, make materialism a constant part of a person's life. The materialism is necessary. You need money even to die as a human being, let alone for medical care. (F23, Turkish)

When it came to their own consumption, many Turks freely acknowledged buying for prestige. Most stated that they are prepared to work very hard to have a 'decent' (literal translation: human) life, and in order not to feel deficient. This was couched as being like others in society or comparable to Westerners. And such comparisons sometimes meant getting ahead in terms of catching up or being at a particular 'standard of living'. 'I want to buy all that is necessary to complete what I am lacking, what is deficient'; '. . . why should I be lacking what everyone else has?'

As with the preceding account that various external factors compel 
materialism, this view (the informants' belief) that materialism is the way of the modern Western world legitimates an entire culture's escalating materialism. The final excuse found is applied at both the cultural and individual level and involves perceptions of deservingness.

\section{I/We Deserve It}

For Romanians, besides comparisons to the West, comparisons are also made to consumption under communism and especially the 'good old days' of the 1970s when supplies were abundant. By both temporal and cross-cultural standards Romanians can easily demonstrate their relative deprivation. In doing so, they are able to feel deserving of luxury and to avoid guilt at having more. By these same relative comparisons, the material desires of Romanians for possessions and the happiness they are thought to bring seem modest:

After the revolution what we believed to be necessities were below the international standards. And I automatically thought people pushed upwards their necessities level. For example, daily hot water became a necessity you don't want to stink anymore. It is difficult to set limits to necessities. (M30, Romanian)

You make love with a man. Your panties are broken or your underwear is old. You are ashamed to switch on the light. Afterward you would like to drink something good; not filthy water. (F25, Romanian)

The invocation of material deservingness based on prior deprivations was not limited to Romanians. Diana, the British student, also remembered from her childhood that, 'The lack of decent clothes really bothered me - I think I've been trying to make up for it ever since.'

Another variant of the deservingness excuse is based on accomplishments that are seen to deserve a reward. Success and achievement are taken as positive values and are not questioned by those in our study.

You enjoy just to have it when you are the only one in town who has it... you have worked for years for it and now you have it. (M28, British)

If I had it [a color television in her family as a child] it was because someone had deserved it. My great-grandfather had worked hard and saved for future generations. (F23, Turkish)

Among the Americans there is often a prejudice that non-achievers such as the homeless, 'bums', and ghetto dwellers, are simply too lazy and insufficiently motivated to achieve and succeed.

I don't think I know anybody who is not materialistic at all.... Because everybody likes nice things. Maybe someone in the ghettos ... well, I think everybody has a little materialism. Even, like a bum on the street. They're just lazy. But I'm sure they'd like to have nice things. They just care more about their booze. They're just not motivated enough. (F23, American) 
Many Turks expressed a sense of pity for the poor and a desire to help them. But nonmaterialism was generally seen to involve a lack of ambitions - the choice of a poverty culture over hard work.

Whether deservingness is based on prior deprivations or achievements and whether it is invoked at a cultural or individual level, it is not seen to be an excuse that redeems materialism as something good. Nor do the other excuses based on external pressures and the ways of the modern world. Even the justifications that there are benign varieties of materialism when it involves joyous connoisseurship, instrumentalism, or altruism, all imply that the more normal variants of materialism are bad for the person or society. But through these accounts most informants were able to reconcile their own ostensive materialism or material aspirations with the negative views of materialism prevalent in their cultures. For those who did not, the most common account was to deny (rightly or wrongly) that they are materialistic. For the majority who did offer accounts of their materialism, it seems to be the negative character of materialism, in their own minds, that makes people feel it necessary to offer accounts for their consumption at all.

\section{CONCLUSIONS: CULTURE AND MATERIALISM AS A MORAL ISSUE}

The informants were eager to provide uninvited accounts to rationalize or legitimize their personal materialism. While they generally see materialism as vain, foolish, pathetic, wasteful, unfulfilling, shallow, invidious, haughty, and misguided, it is nevertheless alluring. Materialists have the things that many of us think we want but cannot afford. When materialistic people display these desiderata, such display generates a mixture of desire, admiration, envy, and resentment. Associating such consumption with ambition, success, and empowerment make it seem admirable, alluring, and enviable to the informants. But because materialism is still seen as a 'bad' way of relating (in practice or in aspirations) to wealth and possessions, further justifications or excuses are needed to engage in such behavior, even in the prototypically materialistic United States.

Each of the cultures studied employs different ways through which the negative social construction of materialism is subverted in order to account for personal materialism. While we cannot argue that these informants necessarily reflect their cultures, it appears that materialism is taken for granted in the US, enthusiastically embraced in Romania, slightly less enthusiastically embraced in Turkey, and bifurcated into acceptable refined 'materialism' (to which the label is not applied) and unacceptable unrefined materialism in Western Europe. Informants from each region point to external materialistic pressures (e.g. television, films, advertising, popular culture manifestations), but Americans and 
Western Europeans talk about having been raised in this environment since birth, whereas Romanians discuss it as a world they have been facing only since 1989 and Turks see it as a world that has been getting increasingly familiar since the 1980s.

In Western Europe, besides altruism and deservingness, individualistic joyous connoisseurship is a commonly invoked means of elevating personal consumption above what is seen as vulgar materialism. Western European informants stress that materialism is American. This characterization of materialism as American indicates that the relative cultural comparison offered by de Tocqueville in the early 19th century has become popular and persistent. Middle-class Europeans have for at least a century and a half seen themselves as pursuing an aesthetic variant of consumption that is vastly superior to the crass commercialism attributed to American consumers (Leach, 1993: 100).

By contrast, in America anti-aristocratic individualism, Puritan perspectives, and lesser class awareness, along with the egalitarian myth of a classless society are paramount (see Lears, 1994). In the US the common accounts informants provided for materialistic behavior include describing it as instrumental rather than terminal materialism, justifying it with claims of altruism, and excusing it based on achievement-based deservingness or as due to external pressures. The lingering Puritan ideology of self-discipline, self-denial, and the precedence of the work ethic over hedonism may underlie the achievement-based deservingness justification (see Dröge et al., 1994; Schudson, 1991). Puritanism, and the related capitalist economic emphasis on utilitarianism also legitimates consumption constructed to be instrumental (see Campbell, 1994).

The terminal/instrumental distinction found among Americans takes on a different rationale among poorer Turks and Romanians. If poverty is experienced as a lack of control, consumption is a way of obtaining control (Douglas and Isherwood, 1979). The empowerment of having may be something that goes without saying in the West where students already feel free, independent, and relatively secure, and hence do not voice a desire for personal power.

In Turkey, altruistic consumption, instrumentalism, uncalculated pleasure, and pursuit of modernity are the commonly cited accounts for conspicuous or materialistic consumption. Turkish informants' accounts may reflect a collective hedonism. Traditional collectivistic norms include moderation, not shaming others, approval of abundance in private but modesty in public (so as not to provoke envy), sharing, and spending with and for other people (Ülgener, 1981). The secularly and religiously sanctioned Ottoman hedonism and spiritual romanticism celebrated consumption if equity and justness were observed (Bulaç, 1987). In Islam, pleasure is not to be condemned as evil, and Islamic ethics see wealth as good or neutral if it is spent for others, for the collective 
welfare (and not saved or invested). This heritage suggests that Turkey may have been quite familiar with materialism in its own way and ready for the transformation to 'Western' materialism associated with modernity (in the popular imagination as well as by the informants).

The same is true in Romania, although the nature of the heritage differs. In Romania irresistible recent external forces and deservingness based on prior deprivations are the most frequently cited excuses for materialism, which is also seen less negatively and as pervasive and practical in today's Romania. Deprivations under communism and Ceauçescu bred great feelings of deservingness (see Belk, 1997). These conditions left Romanians ripe for the enthusiastic explosion of materialism they are now experiencing.

It is significant that materialism has become so quickly entrenched and widely accepted in formerly Communist Romania. If this pattern holds for other developing and marketizing economies, as appears likely (see Belk, 1988; Shultz, Belk, and Ger, 1994), then the immediate future of materialism is one of further growth in consumption aspirations around the world. Each culture finds a culturally appropriate way to justify its own high level consumption behavior and aspirations. The meaning of what is justifiable and legitimate draws from local cultural repertoires. While there are other dynamics involved (e.g. Arnould, 1989; Belk, 1997), the role of accounts in reconciling more traditional cultural values and emerging and revived materialistic behaviors is a neglected and promising focus for understanding the global growth of consumer culture.

The role and nature of accounts are also significant in understanding an understudied aspect of consumption: the nature of consumption as a moral (as well as a social and cultural) project (see Campbell, 1994; Miller, 1995). Although there may be no one proper way to consume, consumers use various accounts to construe their materialistic consumption as moral. They draw from various ethics prevalent in their cultures to make their consumption moral, legitimate, or justifiable. Accounts help us understand what people themselves actually think they are doing and how they make their consumption worlds moral.

As Campbell (1990) argues, individuals are not solely self-interested beings attempting to impress others or to secure social positions, they are also moral beings. Individuals are 'reluctant to engage in acts which they cannot satisfactorily justify to themselves' (Campbell, 1990: 42). They attempt to conduct themselves to fulfill and assure character ideals. Justification is thus 'an integral ingredient of action, in practice not fully separable from its motivation' (Campbell, 1990: 42). Hence, accounts provide insight into the motivations behind materialism.

Accounts that moralize and motivate materialistic consumption are woven within and through an ambiguous and diverse collection of moral 
codes. Foucault (1990) identifies three aspects of morality. First, a moral code is 'a set of values and rules of action that are recommended to individuals through the intermediary of various prescriptive agencies such as the family ... educational institutions, churches, and so forth' (1990: $25)$. But this prescriptive ensemble involves a complex interplay of elements that counterbalance and correct one another, and cancel each other out on certain points, thus providing for compromises or loopholes. We can add to that ensemble, other codes that are implicitly or explicitly recommended by global agencies such as the media (television, films, global advertising, and so forth) and that increase the complexity and the loopholes. Another aspect of morality is the manner in which one resigns to moral codes. The third aspect involves the freer manner of evaluating oneself where explicit moral codes are only distantly relevant. Lehtonen (1997) suggests that the relation of consumption to moral ideals is of the third type - consumers follow their own ideals and ethics in the use of money and consumption. Consumers evaluate themselves as moral beings by drawing from multiple, diffuse, and abstract codes and by taking advantage of the loopholes and the inner contradictions of the ensemble that provide room for negotiation.

The accounts our informants offered indicate five types of ethics: romanticism, Protestant utilitarianism, altruistic sociality, generalized sociality - being part of a world of progress, and fairness or equity. The joyous passionate cultivated aestheticism justification of Western Europeans and the uncalculated pleasure and passionate sharing justifications of Turks imply an ethic of romantic hedonism (see Campbell, 1987). Consumption pursued with passion is justified as inflamed, ennobled, and raised above ordinary consumption to the point that it can even be considered praiseworthy rather than blameworthy. It is also suggestive that informants' descriptions of nonmaterialists almost uniformly involved people who had found another source of passion: poetry, helping others, or art. The second account, instrumentalism, implies an economic morality of utility, rationality, and functionality, and a lingering Protestant ethic, whereby wants are made into real or natural needs (see Campbell, 1994). Third, spending for others involve ethics of altruism embedded in sociality. Accordingly, some informants were careful to note that they do or wish to donate to charity, and others justified their spending as benefiting not only themselves, but their loved ones as well. Fourth, both the society/environment and modern ways excuses imply a more generalized sociality ethic - the desirability of being part of the 'world'. However that 'world' is construed differently in different cultures, intertwined with notions of progress and civilization through modernity (Turkish informants) or capitalism (Romanian informants). Western Europeans and Americans may take this progress for granted or see more of its downside than Turks and Romanians who are trying to 
catch up. Finally, one of the more interesting accounts, deservingness, rests on ethics of fairness, justice, and equity. Shabad (1993: 489) observes that 'By referring to oneself as needy, one can evade cruel criticisms - often from oneself - for merely wishing or desiring pleasure.' Especially for those in societies, such as Romania, emerging out of poverty or restricted consumption, exposure to the consumption patterns of the world's affluent is likely to lead to thoughts that 'we deserve it too'. A similar rationale may well account for the explosion of consumer spending in the United States during the years following the deprivations of World War II. On the other hand, the achievement-based deservingness justification, particularly strong among the American informants, is more likely to be related to the Puritan fairness of a well-deserved reward for work.

Thus, romanticism, Protestant utility, altruism and sociality, worldly progress, and fairness and justice may be meta-accounts or the ethics that are used to justify our materialistic behaviors. Although Campbell's romanticism is one of the accounts our informants used, it was not the only one. Even in the age of modern consumption, consumers in different cultures have a repertoire of ethics they use, including the Protestant ethic. The moral - the good, the beautiful, the true - is constructed and assembled with different combinations of historical and contemporary ethics in different cultures, all seeking morality. People resign to moral codes and evaluate themselves as moral beings by negotiating such codes (within their multiplicity and ambiguity) with their own consumption.

Our findings suggest that everyone has a yardstick with which they measure what level and pattern of consumption is enough and good and call most others 'materialistic'. The moving mark of what is enough and pleasurable is negotiated in moral terms. People forge their own consumption patterns and accounts using various cultural codes of what ought to be. The accounts we find indicate the culturally specific nature of subjective morality, and the ethics people draw from in negotiating the contradiction of constructing themselves through their interactions with the 'bad' material world while making their own worlds moral. In this way people can consume materialistically and be/feel moral at the same time. Thus, in practice, consumption and materialism have the chance to grow globally, nourished and moralized by local accounts, while the abstract paradox between the negativity towards materialism versus materialistic aspirations and consumption remains.

\section{Acknowledgements}

We would like to thank Paul Işiou for conducting focus groups in Romania, Nur Bekata Mardin for her help in data collection in Istanbul, and Søren Askegaard, Dominique Bouchet, and Daniel Miller for their helpful comments on earlier versions of this article. 


\section{Note}

1. We owe this insight to Daniel Miller's comments.

\section{References}

Arnould, Eric J. (1989) 'Toward a Broadened Theory of Preference Formation and the Diffusion of Innovations: Cases from Zinder Province, Niger Republic', Journal of Consumer Research 16 (September): 239-67.

Baier, Kurt (1986) 'Justification in Ethics', in J. Roland Pennock and John W. Chapman (eds) Justification: Nomos XXVIII, pp. 3-27. New York: New York University Press.

Belk, Russell W. (1983) 'Worldly Possessions: Issues and Criticisms', in Richard P. Bagozzi and Alice M. Tybout (eds) Advances in Consumer Research, Vol. 10, pp. 514-19. Ann Arbor: Association for Consumer Research.

Belk, Russell W. (1985) 'Materialism: Trait Aspects of Living in the Material World', Journal of Consumer Research 12 (Dec): 265-79.

Belk, Russell W. (1988) 'Third World Consumer Culture', in Marketing and Development: Toward Broader Dimensions, pp. 103-27. Erdoğan Kumcu and A. Fuat Firat (eds) Greenwich, CT: JAI Press.

Belk, Russell W. (1997) 'Romanian Consumer Desires and Feelings of Deservingness', in Lavinia Stan (ed.) Romania in Transition, pp. 191-208. Dartmouth, UK: Dartmouth University Press.

Brewer, John and Porter, Roy, eds (1993) Consumption and the World of Goods. London: Routledge.

Bulaç, Ali (1987) İslam Dünyasında Toplumsal Değişme. Istanbul: Nehir Yayınları.

Campbell, Colin (1987) The Consumer Ethic and the Spirit of Modern Consumerism. Oxford: Basil Blackwell.

Campbell, Colin (1990) 'Character and Consumption: An Historical Action Theory Approach to the Understanding of Consumer Behaviour', Culture and History 7: 37-48.

Campbell, Colin (1994) 'Consuming Goods and the Good of Consuming', Critical Review 8(4): 503-20.

Coleman, James William (1992) 'Crime and Money', American Behavioral Scientist 35 (July/August): 827-36.

Corrado, Michael (1991) 'Notes on the Structure of a Theory of Excuses', Journal of Criminal Law and Criminology 82 (Fall): 465-97.

Csikszentmihalyi, Mihalyi and Rochberg-Halton, Eugene (1981) The Meaning of Things: Domestic Symbols and the Self. Chicago, IL: University of Chicago Press.

Dittmar, Helga (1992) The Social Psychology of Material Possessions: To Have Is To Be. New York: St Martin's Press.

Douglas, Mary and Isherwood, Baron (1979) The World of Goods: Towards an Anthropology of Consumption. New York: Basic Books.

Dröge, Cornelia, Calantone, Roger, Agrawal, Madhu and Mackoy, Robert (1994) 'The Consumption Culture and its Critiques: A Framework for Analysis', Journal of Macromarketing 13 (Fall): 32-45.

Foucault, Michel (1990) The Use of Pleasure, The History of Sexuality, Volume 2, translated by Robert Hurley. New York: Vintage Books.

Fox, Richard Wightman and Lears, T. J. Jackson (1983) The Culture of Consumption: Critical Essays in American History, 1880-1980. New York: Pantheon.

Friedman, Jonathan, ed. (1994) Consumption and Identity. Chur, Switzerland: Harwood Academic Publishers. 
Ger, Güliz (1992) 'The Positive and Negative Effects of Marketing on Socioeconomic Development: The Turkish Case', Journal of Consumer Policy 15(3): 229-54.

Ger, Güliz (1997) 'Human Development and Humane Consumption: Well-Being Beyond the Good Life', Journal of Public Policy and Marketing 16(1): 110-25.

Ger, Güliz and Belk, Russell W. (1996a) 'I'd Like to Buy the World a Coke: Consumptionscapes of the "Less Affluent World" ', Journal of Consumer Policy 19(3): 271-304.

Ger, Güliz and Belk, Russell W. (1996b) 'Cross-Cultural Differences in Materialism', Journal of Economic Psychology 17(1): 55-77.

Ger, Güliz and Belk, Russell W. (1998) 'Constructions of Materialism Across Cultures', working paper.

Ger, Güliz, Belk, Russell W. and Lascu, Dana-Nicoleta (1993) 'The Development of Consumer Desire in Marketizing and Developing Economies: The Cases of Romania and Turkey', in Leigh McAlister and Michael L. Rothschild (eds) Advances in Consumer Research, Vol. 20, pp. 102-7. Provo, UT: Association for Consumer Research.

Glass, Shirley and Wright, Thomas L. (1992) 'Justifications for Extramarital Relationships: The Association Between Attitudes, Behaviors, and Genders', Journal of Sex Research 29 (August): 361-87.

Greenawalt, Kurt (1986) 'Distinguishing Justifications From Excuses', Law and Contemporary Problems 49 (Summer): 89-108.

Hamilton, V. Lee and Hagiwara, Shigeru (1992) 'Roles, Responsibility, and Accounts Across Cultures', International Journal of Psychology 27 (April): 157-79.

Hong, Lawrence K. and Duff, Robert W. (1977) 'Becoming a Taxi-Dancer', Sociology of Work and Occupations 4 (August): 327-42.

Hunt, Jennifer and Manning, Peter K. (1991) 'The Social Context of Police Lying', Symbolic Interaction 14 (Spring): 51-70.

Inglehart, Ronald (1981) 'Post-Materialism in an Environment of Insecurity', American Political Science Review 75(4): 880-900.

Kemper, Steven (1993) 'The Nation Consumed: Buying and Believing in Sri Lanka', Public Culture 5: 377-93.

Leach, William R. (1993) Land of Desire: Merchants, Power, and the Rise of a New American Culture. New York: Vintage.

Lears, Jackson (1994) Fables of Abundance: A Cultural History of Advertising in America. New York: Basic Books.

Lehtonen, Turo-Kimmo (1997) 'Any Room for Aesthetics? Heavily Indebted Consumers' Shopping Practices', paper presented at The Sixth Interdisciplinary Conference on Research in Consumption, Fredrikstad, Norway, 17-19 August.

McGraw, Kathleen M. (1990) 'Avoiding Blame: An Experimental Investigation of Political Excuses and Justifications', British Journal of Political Science 20 (January): 119-31.

Miller, Daniel (1995) 'Consumption as the Vanguard of History', in Daniel Miller (ed.) Acknowledging Consumption, pp. 1-57. London: Routledge.

Mukerji, Chandra (1983) From Graven Images: Patterns of Modern Materialism. New York: Columbia University Press.

Needleman, Jacob (1991) Money and the Meaning of Life. New York: Doubleday. Richins, Marsha and Dawson, Scott (1992) 'A Consumer Values Orientation for Materialism and its Measurement: Scale Development and Validation', Journal of Consumer Research 19(3): 303-16. 
Richins, Marsha and Rudmin, Floyd W. (1994) 'Materialism and Economic Psychology', Journal of Economic Psychology 15 (June): 217-31.

Rudmin, Floyd W. and Richins, Marsha, eds (1992) Meaning, Measure, and Morality of Materialism. Provo, UT: Association for Consumer Research.

Schudson, Michael (1991) 'Delectable Materialism: Were the Critics of Consumer Culture Wrong All Along?', The American Prospect Spring: 26-35.

Scott, Marvin B. and Lyman, Stanford M. (1968) 'Accounts', American Sociological Review 33 (February): 46-61.

Seabrook, Jeremy (1978) What's Gone Wrong? Why Hasn't Having More Made People Happier?. New York: Pantheon.

Shabad, Peter (1993) 'Resentment, Imagination, Entitlement: The Transformation of Unconscious Wish into Need', Psychoanalytic Dialogues 3(4): 481-94.

Shultz, Clifford II, Belk, Russell and Ger, Güliz, eds (1994) Consumption in Marketizing Economies. Greenwich, CT: JAI Press.

Snyder, C.R., Higgins, Raymond L. and Stucky, Rita J. (1983) Excuses: Masquerades in Search of Grace. New York: John Wiley \& Sons.

Stallybrass, Peter (1998) 'Marx's Coat', in Patricia Spyer (ed.) Border Fetishisms: Material Objects in Unstable Spaces, pp. 183-207. London: Routledge.

Ülgener, Sabri (1981) İktisadi Çözülmenin Ahlak ve Zihniyet Dünyası. Istanbul: Der Yayinlari.

Wachtel, Paul L. (1989) The Poverty of Affluence: A Psychological Portrait of the American Way of Life. Philadelphia, PA: New Society Publishers.

Wuthnow, Robert (1994) God and Mammon in America. New York: Free Press.

- GÜLIZ GER is Professor of Marketing at the Faculty of Business Administration, Bilkent University, 06533 Ankara, Turkey. [email: ger@bilkent.edu.tr]

- RUSSEll W. BeLK is N. Eldon Tanner Professor of Business Administration at the David Eccles School of Business, University of Utah, Salt Lake City, UT 84112, USA. [email: mktrwb@business.utah.edu] 